Aleksandar Grubor ${ }^{1}$

Ksenija Leković ${ }^{2}$

Slavica Tomic ${ }^{3}$

University of Novi Sad,

Faculty of Economics in Subotica
ORIGINAL SCIENTIFIC ARTICLE doi:10.5937/ekonomika1904001G Received: November, 07. 2019. Accepted: December, 09. 2019.

\title{
RURAL TOURISM MARKETING OF THE DANUBE REGION ${ }^{4}$
}

\begin{abstract}
Within tourism, as one of the largest and fastest-growing world industries, a prominent place is taken up by separate, selective forms of tourism. Rural tourism enables consumers to return to the natural setting and relief from pressure and stress emerging in urban environments. As eco-friendly travel into relatively well-preserved areas, rural tourism features as a significant element of sustainable tourism, economic and social development of rural areas. In view of this, the entire management, realization and implementation of the marketing strategy of developing rural tourism should be based on a compromise of interests of different and numerous stakeholders. The subject of this paper is the Danube Region and rural tourism of this region, and the objective is to emphasise the significance of further development of this special, selective form of tourism by applying marketing concept. Secondary data and methods of induction, deduction, synthesis and analysis were used for the purpose of this writing this paper
\end{abstract}

Keywords: tourism, rural tourism, marketing, the Danube region

JEL classification: M31, Z32

\section{МАРКЕТИНГ РУРАЛНОГ ТУРИЗМА ДУНАВСКОГ РЕГИОНА}

\section{Апстракт}

У оквиру туризма, као једне од највећих и најбрне растућих светских индустрија, издвајају се посебни, селективни облиии туризма попут руралног туризма. Рурални туризам омогућава потрочачима повратак природном амбијенту и растерећене од притиска и стреса који настаје у урбаним срединама. Као еколочко путоване у релативно очувана подручја, рурални туризам представъа значајан елемент одрживог туристичког, економског и социјалног развоја руралних области. При том, иелокупно управљане, реализација и имплементација маркетинг стратегије развоја руралног туризма треба да се базира на компромису интереса различитих и многобројних стејкхолдера. Предмет рада

\footnotetext{
${ }^{1}$ agrubor@ef.uns.ac.rs

${ }^{2}$ ksenija.lekovic@ef.uns.ac.rs

3 tomics@ef.uns.ac.rs

${ }^{4}$ The paper is prepared within the project III 46006 Sustainable agriculture and rural development in the function of accomplishing strategic objectives of the Republic of Serbia in the Danube region, financed by the Ministry of Education, Science and Technological Development of the Republic of Serbia in the period 2011-2019.
} 
представль Дунавски регион и рурални туризам тог региона а циљь се огледа у истицаньу значаја даљег развоја овог посебног, селективног облика туризма применом маркетинг кониепта. За потребе писать рада спроведено је истраживате за столом, коришћени су секундарни подаци и методе индукиије, дедукиије, синтезе и анализе.

Кључне речи: туризам, рурални туризам, маркетинг, Дунавски регион

\section{Introduction}

Numerous changes on the market caused by industrialization have led to a significant trend - migration of inhabitants from villages to towns, resulting in the problem or deagrarization of numerous rural areas. A possible solution to the problem is to support sustainable rural development and to develop rural tourism as a special, selective form of tourism. The environmental aspects of rural tourism are one of the ways to contribute to solving this problem, the most important of them being: direct impact on preservation of and increase in agricultural areas, securing additional income to local population and job opportunities. (Franić \& Grgić, 2002).

In accordance with the above, within the Danube Region, connection between sustainable agriculture, sustainable rural development and sustainable development of tourism, that is, its special form, rural tourism has a special significance. Such integrated approach to sustainable development of the Danube Region meets the basic objectives of the EU Strategy for the Danube Region - connectedness and communication, environmental protection, socio-economic and institutional development and strengthening regional cooperation (Štetić et al., 2014).

The subject of the paper is the Danube Region and development of a special form of tourism - rural tourism - in this area. The objective is reflected in pointing out the significance of development of rural tourism by applying marketing concept. Desk research was conducted for the purpose of writing the paper, and data from secondary sources were used. In addition to the introduction and the conclusion, the paper includes three wholes structured from general to specific content.

\section{Rural tourism}

Tourism is one of the world's greatest and fastest-growing industries, the development of which has resulted in diversification of tourist products and tourist destination (Pato \& Kastenholz, 2017). New, selected forms of tourism have appeared as a consequence of the above mentioned processes. (Sharpley \& Vass, 2006). The "new" forms of tourism aim to overcome problems generated by mass tourism (Weaver \& Jin, 2016). As early as the in 1990s, Poon (1993) pointed to the emergence of the so-called "new, hybrid tourist", seeking to experience something new and different, to travel independently and experience tourist destination without destroying them. Such "new" tourists differ from tourists - consumers of mass tourism. Table 1 shows the difference between the "new" and the "old" tourists. 
Table 1. Characteristics of the "new" and the "old" tourists

\begin{tabular}{|l|l|}
\hline \multicolumn{1}{|c|}{ Characteristics of the "new" tourists } & \multicolumn{1}{c|}{ Characteristics of the "old" tourists } \\
\hline $\begin{array}{l}\text { Spontaneous behaviour with changes in the } \\
\text { manner of choosing travel }\end{array}$ & $\begin{array}{l}\text { Homogenous segments of predictable } \\
\text { behaviour }\end{array}$ \\
\hline $\begin{array}{l}\text { With experience in travel and desire for } \\
\text { adventure and entertainment }\end{array}$ & Travel is novelty for them \\
\hline Have quality of the total experience in focus & $\begin{array}{l}\text { Do not pay attention to the quality of tourist } \\
\text { service }\end{array}$ \\
\hline $\begin{array}{l}\text { Wish to manage their own leisure time and } \\
\text { willing to take risks }\end{array}$ & Feel secure as a part of a large group \\
\hline
\end{tabular}

Source: Adapted from Štetić et al. (2014) Posebni oblici turizma Dunavskog regiona Srbije. Institut za ekonomiku poljoprivrede, Beograd, str. 17.

In this sense, alternative, special forms of tourism such as eco-tourism, rural tourism, cultural tourism and others, fully targeted to consumers and their specific needs emerge as opposition to mass tourism (Mihailović \& Moric, 2012). Demand for such, special forms of tourism has clearly manifest specific features: (a) expressed wish of tourists-consumers for authenticity; (b) expressed wish of tourists-consumers for experience in local setting and (c) expressed wish of tourists-consumers for appreciation of the host (Todorović \& Štetić, 2009).

Rural tourism features as a significant element of sustainable tourist, economic and social development of rural areas (Krajnović et al., 2011). Sustainable development refers to a harmonious relationship between nature and ecology aimed at preserving natural resources for present and future generations, whereas sustainable tourism refers to tourist movements accompanied by meeting social and economic needs and preservation of cultural and historic heritage of destinations (Štetić, 2002). Given that sustainable tourism features as an essential element of socio-economic development of a country, Milenković (2006) finds the following to be necessary: (a) to base its development on the criterion of sustainability; (b) to raise the level of consumers' awareness of tourism; (c) to define a program for providing sustainable development of tourism and (d) to disseminate knowledge on sustainable technologies in tourism.

The notion "rural" has transformed in recent decades from the traditionally "agrarian" notion into a notion increasingly related to social, cultural and economic context (Okech et al., 2012). Rural tourism can be defined as eco-friendly travel to relatively wellpreserved areas for entertainment and enjoyment in nature (Radović et al., 2018). Similarly, Ružić (2009) states that rural tourism enables consumers to return to the natural setting and relief from pressure and stress appearing in urban environment. In addition to the above, the same author points out that developing rural tourism encompasses the entire rural environment connected with the comprehensive setting of rural life - architecture, plant and animal world, culture, tradition etc. On the other hand, rural tourism creates conditions for development of entrepreneurship and opens development opportunities for two groups of stakeholders. The first group comprises subject directly involved in this form of tourism (e.g. subjects involved in accommodation or food preparation), whereas the other group comprises subjects indirectly involved as part of rural tourism (e.g. variety shops) (Wilson et al., 2001). Okech, Haghiri \& George (2012) state two basic reasons why it is essential to develop tourism in rural areas: 
- Increasing the number of people (local population) involved in developing rural tourism - one of the ways to increase employment rates in rural areas is reflected in developing tourism in these areas.

- Providing wider benefits to rural areas - developing tourism in rural areas enables economic growth, stabilisation, employment, stops depopulation, builds infrastructure, revives old crafts, increases the opportunity of contact with local population, ensures environmental protection etc.

What separates rural tourism in comparison with other, special, selective forms of tourism is authenticity and tradition. Motives of consumers/tourists visiting rural tourism destination can be explained by push and pull factor theory (Dann, 1981). According to this theory, push factors are internal motives and urges driving consumers to travel, whereas pull factors includes all external forces and characteristics of a tourist destination attracting consumers to visit them. Thus, in the context of rural tourism, push factors represent consumers' desire to escape the everyday stressful urban life, whereas pull include peace, simplicity, authenticity, relaxation, greenery, clean air, local gastronomy and local customs (Urry, 2002). Similarly, Goeldner \& Ritchie (2005) divide motives making rural tourism interesting to consumers/tourists into four groups: (1) physical (e.g. relaxation); (2) cultural (introduction to new cultures, customs and lifestyles); (3) interpersonal (meeting new people) and prestige (introspection and self-actualisation). However, one must bear in mind that although consumers/tourists enjoy the old-fashioned lifestyles during their visit to a rural tourist destination, its contents need to be adapted to their needs and expectation. Thus, the offer of the rural tourist destination should include a broad spectrum of activities such as hunting, fishing, horse riding, walking, eco-tourism, ethno-tourism, even elements of health and wellness tourism (Rodrigues et al., 2010).

\section{The role of marketing in the development of rural tourism}

Technological development and increasingly important application of the Internet change the methods of communicating and establishing consumer relationships. This trend gains significance in a situation when the offer - the product/service is dislocated in relation to the target segment, as in the case of rural tourism (Gossling \& Lane, 2015). Also, it must be pointed out that the offer of rural tourist destination is based on appeal, individual approach and tradition. On the other hand, under the influence of the aforementioned trend, consumers/tourists are becoming increasingly independent and increasingly involved in the process of selecting tourist destinations (King, 2002). The link between supply and demand in this case can be marketing with the task to connect consumers/tourists and local tourist destination, as well as achieving customer loyalty.

Dinis (2006) states two basic objectives to be achieved by applying marketing in rural areas:

- to enable rural areas to be more competitive and

- provide conditions for higher quality of life for economically active population of the areas

Similarly, Kostić-Stanković (2013) points out the following objectives of application of marketing within rural development: 
- creating and improving competitiveness by emphasising the differential advantages of rural areas

- strengthening local infrastructure,

- developing and promoting rural areas by pointing out initiatives and strategies of rural development

- attracting, building and maintaining long-term relations with foreign partners/ investors and

- $\quad$ protecting and improving the environment in accordance with sustainable rural development.

The specific features of applying marketing in rural tourism stems from the nature of tourist service (Mihailović, 2011). Above all, one must bear in mind the seasonal character of demand, where marketing's task is reflected in the attempt to extend the season, and the application of marketing method for adapting to its varying intensity. Furthermore, an unavoidable characteristic is high fixed costs arising from the attempt to satisfy consumers/ tourists visiting rural destinations, so that marketing managers' task is to create an offer that will absorb sufficient income to cover them. Finally, consumers/tourists expect offer consisting of tourist offers that will meet all their expectations and needs. This is an offer comprising a combination of not only of various services but also physical products, events and experiences.

Appreciating the specific features of tourist offer, Pato \& Kastenholz (2017) propose a useful marketing approach to rural tourism. It is the demand management strategy in the context of integrated and sustainable marketing approach. Such an integrated marketing approach should be based on: (a) attempt to discover what it is that a rural tourist destination has to offer (what?), (b) which segment of consumers/tourists has the time, money and desire to travel and visit such a type of tourist destination (who?) and how to reach such consumers/ tourists, meet their expectations and needs and build loyalty (how?).

Marketing management in the area of rural tourism as a special, selective form of tourism is characterised by the following (Skoko \& Jugo, 2007; Krajnović et al., 2011):

- The majority of subjects involved in tourist offer of rural areas are unable to apply various marketing methods, so that it is necessary to perform marketing networking of all stakeholders. Thus, marketing networking should be conducted at city or municipal levels, at tourist cluster level, at regional and national level.

- In addition to basic resources forming the tourist product and offer of a rural tourist destination - agricultural products, climate, natural attractions, local population, cultural landmarks, tradition, customs etc., - a very important role is also played by accompanying infrastructure - roads, signals, bicycle paths, walking paths etc. All of these lead to the conclusion on the importance of the role of the public sector in the development of rural tourism.

The entire management, realisation and implementation of marketing strategy of rural tourism development should be based on a compromise of interests of various stakeholders. 


\section{The basic guidelines of further development of rural tourism of the Danube Region by application of marketing concept}

The Danube Region is a functionallyconnected space defined by its basin(Communication from the Commission to the European Parliament, the Council, the European Economic and Social Committee and the Committee of the Regions, downloaded from https://ec.europa. eu/regional_policy/sources/docoffic/official/communic/danube/com2010_715_danube_ sr.pdf). At its length of $2860 \mathrm{~km}$, the Danube flows through 10 countries and extends to 19 countries, where the largest part of its basin belongs to Romania (29\%). It is a region possessed of exceptional natural beauty, rich history, tradition and culture. The EU Strategy for the Danube Region (EUSDR) encompasses 14 countries along the Danube (Austria, Bulgaria, the Czech Republic, Croatia, Hungary, Germany, Slovakia, Slovenia, Romania, Bosnia and Herzegovina, Montenegro, Moldavia, Ukraine and Serbia), with over 112 inhabitants. The strategy is based on four pillars, within which specific actions for co-operation determine priority areas (Table 2). Table 2 clearly shows how promoting culture and tourism features as one of priority areas within the development of the Danube Region.

Table 2. 4 pillars of the EU Strategy for the Danube Region (EUSDR)

\begin{tabular}{|l|}
\hline 1. CONNECTING THE REGION \\
\hline To improve mobility and transport connections \\
\hline To encourage development of sustainable energy \\
\hline To promote culture and tourism \\
\hline 2. PROTECTING THE ENVIRONMENT \\
\hline To restore and maintaining the quality of waters \\
\hline To manage environmental risks \\
\hline To preserve biodiversity, landscapes and the quality of air and soils \\
\hline 3. BUILDING PROSPERITY \\
\hline To develop knowledge society \\
\hline To support competitiveness of enterprises \\
\hline To invest in people and skills \\
\hline 4. STRENGTHENING THE REGION \\
\hline To step up institutional capacity and cooperation \\
\hline To work together to promote security and tackle organised and serious crime \\
\hline
\end{tabular}

Source:https://ec.europa.eu/regional_policy/sources/docoffic/official/communic/danube/com2010_715_ danube_sr.pdf

The issue of rural development in the European Union (the majority of countries encompassed by the Strategy are EU members) is of great importance, especially bearing in mind the fact that about $90 \%$ of the territory of the EU comprises rural and medium rural areas (Đokić, 2019). The importance of rural tourism is reflected in the interaction of agricultural production, production of traditional products, preservation of historic and cultural heritage, tradition and traditional, local gastronomy. Wilson et al. (2001) point out that the development of tourism in rural areas is based on the following elements: total physical product, good local governance, support of local government, sources of finance for tourism, strategic planning, coordination and cooperation between stakeholders and local government, coordination and 
cooperation between rural tourist entrepreneurs and wide support of the local community to development of tourism. In addition to all of the above, one must add the fact that Europe, with over 200,000 households and over 2 million beds in rural tourism, has completed the phase of developing rural tourism and faces the challenges of the subsequent phase, the most important being lack of high-quality and preserved areas (with increasing competition, need for integration within rural areas and need for building partnerships between all stakeholders in rural tourism (Štetić et al., 2013).

The Danube represents exceptional tourist potential. In order to position it on the market as successfully as possible, it is necessary to apply a development model that would provide the Danube with competitive advantage in relation to other rivers. Such a model is based on customer/tourist satisfaction, satisfaction of the local tourist community, preserving the quality of environment and sustainable development of tourism (Štetić et al., 2014). Further development of rural tourism in the Danube basin and its integration into the rural space attains numerous economic and non-economic effects influencing the development of the total local community. The above is reflected through: (a) developing underdeveloped areas and their inclusion into the tourist offer; (b) employing as many household members as possible; (c) achieving "invisible" export by placement of surplus products of rural households (d) selling traditional products - handicraft products; (e) creating opportunities for return of population into abandoned rural areas; (f) extending the base for developing tourism and increasing income and (g) creating a basis for expanding the real circle of tourist demand (Štetić, 2007). Viewed like this, tourism (and local tourism as its special form) should be one of priority industries providing the Danube basin (including Serbia, which belongs to this region) an opportunity to earn income, open new jobs and develop underdeveloped areas (Tomić \& Stoiljković, 2015; 2013).

\section{Conclusion}

The role and importance for the economy of a country or a region are multiple. Its effects are expressed by showing tourist sales and income on the one hand and influence it achieves on complementary activities on the other (Štetić et al., 2014). Developing rural tourism features as one of the solution that would enable multiple positive effects in rural areas with appropriate economic, infrastructural, organisational, organisational and educational incentives.

Further development of rural tourism in the Danube region can, primarily, improve conditions of living in this area. Through an integrated approach and development model, this special, selective form of tourism connects agricultural production, services, restoration and maintenance of cultural, educational, communal and social infrastructure. This is a way to create a base for creating new jobs, additional income to local population, further improvement and education of local population and, generally, reviving the trend of return of population to smaller, rural areas. 


\section{References}

Dann, G. (1981). Tourism motivation: an appraisal. Annals of Tourism Research, 8, 187-219.

Dinis, A. (2006). Marketing and innovation: useful tools for competitiveness in rural and peripheral areas. European Planning Studies, 14(1), 9-22.

Đokić, M. (2019). Sustainable agricultural and rural development in the European Union. Economics of Sustainable Development, 3, 29-43.

Franić, R., Grgić, Z. (2002). Agroturizam na obiteljskom poljoprivrednom gospodarstvu u Hrvatskoj-Pretpostavke i izgledi razvitka, studija slučaja. Agriculturae Conspectus Scientificus, 67(3), 131-141.

Goeldner, C.R., Ritchie, J.R.B. (2005). Tourism: Principles, Practices, Philosophies. John Wiley \& Sons, Hoboken.

Gossling, S., Lane, B. (2015). Rural tourism and the development of Internet-based accommodation booking platforms: a study in the advantages, dangers and implications of innovation. Journal of Sustainable Tourism, 23(8/9), 1386-1403.

King, J. (2002). Destination marketing organizations - connecting the experience rather than promoting the place. Journal of Vacation Marketing, 8(2), 105-108.

Kostić-Stanković, M. (2013). Marketing i ruralni razvoj. Stalna konferencija gradova i opština - Savez gradova i opština Srbije, Beograd.

Krajnović, A., Čičin-Šain, D., Predovan, M. (2011). Strateško upravljanje razvojem ruralnog turizma - problem i smjernice. Oeconomica Jadertina, 1, 30-45.

Mihailović, B. (2011). Marketing in Tourism: Principles of Management. CPI, Podgorica.

Mihailović, B., Moric, I. (2012). The role of marketing philosophy in rural tourism development. Tourism and Hospitality Management, 18(2), 267-279.

Milenković, S. (2006). Međusobni odnosi turizma i životne sredine. Ekonomski fakultet, Kragujevac.

Okech, R., Haghiri, M., George, B. (2012). Rural tourism as a sustainable development alternative: an analysis with special reference to Luanda, Kenya. Cultur, 6(3), 3654 .

Pato, L., Kastenholz, E. (2017). Marketing of rural tourism - a study based on rural tourism lodgings in Portugal. Journal of Place Management and Development, 10(2), 121-139.

Poon, A. (1993). Tourism, Technology and Competitive Strategies. C.A.B. International, Wallingford.

Radović, G., Košić, K., Demirović, D. (2018). Finansiranje kao ključni element strategije održivog razvoja ruralnog turizma u Republici Srbiji. Ekonomika poljoprivrede, 65(1), 413-426.

Rodrigues, A., Kastenholz, E., Rodrigues, A. (2010). Hiking as a relevant wellness activity: results of an exploratory study of hiking tourists in Portugal applied to a rural tourism project. Journal of Vacation Marketing, 16, 331-343. 
Ružić, P. (2009). Ruralni turizam. Institut za poljoprivredu i turizam Poreč, Pula.

Sharpley, R., Vass, A. (2006). Tourism, farming and diversification: an attitudinal study. Tourism Management, 27(5), 1040-1052.

Skoko, B., Jugo. D. (2007). Uloga odnosa s javnošću u razvoju seoskog turizma: perspektive razvoja ruralnog turizma. Hrvatski farmer, 387-401.

Štetić, S. (2002). Uspostavljanje ravnoteže održivog razvoja i ekonomskog rasta kroz turizam. Prirodno-matematički fakultet, Departman za geografiju, turizam i hotelijerstvo, Novi Sad.

Štetić, S. (2007). Posebni oblici turizma. LI, Beograd.

Štetić, S., Cvijanović, D., Šimičević, D. (2014). Posebni oblici turizma Dunavskog regiona Srbije. Institut za ekonomiku poljoprivrede, Beograd.

Štetić, S., Šimičević, D., Curčić, N. (2013). Specifični oblici turizma. LI, Beograd.

Todorović, M., Štetić, S. (2009). Ruralni turizam. Geografski fakultet, Beograd.

Tomić, S., Stoiljković, A. (2013). Turistička kretanja u Srbiji. Anali Ekonomskog fakulteta u Subotici, 49(30), 81-96.

Tomić, S., Stoiljković, A. (2015). The Competitiveness of Serbia on the International Tourism Market. Strategic Management, 20(3), 37-43.

Urry, J. (2002). The Tourist Gaze. Sage, London, UK.

Weaver, D.B., Jin, X. (2016). Compassion as a neglected motivator for sustainable tourism. Journal of Sustainable Tourism, 24(5), 657-672.

Wilson, S., Fesenmeier, D.R., Fesenmeier, J., John, C. (2001). Factors for success in rural tourism development. Journal of tourism research, 40(2), 132-138.

Saopštenje Komisije Evropskom parlamentu, Evropskom savetu, Evropskom socioekonomskom komitetu i Regionalnom komitetu, preuzeto: https://ec.europa. eu/regional_policy/sources/docoffic/official/communic/danube/com2010_715_ danube_sr.pdf (20.11.2019.) 